\title{
Urbanization in Small Cities and Their Significant Implications on Landscape Structures: The Case in Ethiopia
}

\author{
Berhanu Keno Terfa ${ }^{1}$, Nengcheng Chen ${ }^{1,2}{ }^{(\mathbb{D}}$, Xiang Zhang ${ }^{1, *(\mathbb{D})}$ and Dev Niyogi ${ }^{3,4}$ \\ 1 State Key Laboratory of Information Engineering in Surveying, Mapping, and Remote Sensing, \\ Wuhan University, Wuhan 430079, China; berekeno@whu.edu.cn (B.K.T.); cnc@whu.edu.cn (N.C.) \\ 2 Collaborative Innovation Center of Geospatial Technology, Wuhan 430079, China \\ 3 Department of Agronomy-Crops, Soils, Environmental Sciences, Purdue University, \\ West Lafayette, IN 47907, USA; dniyogi@purdue.edu \\ 4 Department of Earth, Atmospheric, and Planetary Sciences, Purdue University, \\ West Lafayette, IN 47907, USA \\ * Correspondence: zhangxiangsw@whu.edu.cn; Tel.: +86-158-7147-2170
}

Received: 13 January 2020; Accepted: 6 February 2020; Published: 8 February 2020

\begin{abstract}
Fundamental ideas concerning urbanization are primarily based on studies performed in large cities. It is of interest to study whether or not similar phenomena take place in smaller cities. Small cities are an inherent component of urbanization, and in the future, the majority of globalization is expected to occur in small and mid-sized cities. Understanding the effects of small cities on landscape structures is, therefore, an essential component in planning city land expansion. Accordingly, this study focused on six towns of the Oromia Special Zone Surrounding Finfinnee, Ethiopia, which is broadly known to be experiencing dramatic growth. Time-series Landsat images from 1987 to 2019 with an integrated method, landscape metrics, and built-up density analysis were employed to characterize and compare the dynamics of landscape structures, urban expansion patterns, process, and overall growth status in the towns. The results highlight that all the towns experienced accelerated growth in the built-up areas and highly scattered nature in spatial growth. Landscape ecology analysis confirmed a highly fragmented urban landscape, a significant loss of natural land covers, and disconnected and complicated agro-vegetation patches in all towns, suggesting a lack of rigorous implementation of the master plan. Results also indicated that the Oromia Special Zone surrounding Finfinnee has failed to control urban sprawl to surrounding ecological sensitive areas. The study results, more broadly, highlight that the small cities would have a limited physical and demographic footprint and relatively less contribution to the national economic agglomeration; nonetheless, they can have a notable and important impact in terms of their ecological and environmental influence. Hence, the study suggests policies for monitoring such dynamics and protecting agro-environmental connectivity with particular focus on the small cities.
\end{abstract}

Keywords: Oromia Special Zone Surrounding Finfinnee; landscape; spatial patterns; remote sensing; towns

\section{Introduction}

Rapid population growth and the related need for housing and other amenities have resulted in an increasing urbanized land cover, mostly along the major roads and rural countryside, which is typically scattered and inefficient in resource utilization [1,2]. The scattered urban growth and disaggregated landscape structures as a result of human activities also influence the function and structure of the ecosystem [3-5]. Dispersed urban development can pose a challenge for planning 
infrastructure and services. Whereas a compact spatial form can assist in implementing an enhanced transportation system as well as minimize the consumption of traffic energy-efficiency and resource utilization such as water pipe networks and drainage system [6,7]. However, some studies argue that the potential for damage to urban green spaces [8], increased traffic congestion, pollution, and crowded services [9] are notable shortcomings of compacting urban development. Even though there is some controversy regarding spatial growth types, the general agreement is that the urban spatial morphology can determine the social, environmental, and ecological situations of a city. Consequently, exploration of the urban spatial dynamics and landscape structures analysis continues to of interest due to its high importance in creating sustainable cities.

Several studies have investigated the effects of urban expansion on the landscape composition and configuration [10-12], investigating the existing and projected urban land dynamics [13], and exploring the patterns and possible drivers [14,15]. However, most of these studies have concentrated on large metropolitan regions due to their significant influences on socio-economic and environmental conditions [14,16]. In contrast, the smaller cities and towns, where scattered urban growth is more prominent [17-19], have been given little attention [20-22]. As a result, the conceptual ideas regarding urbanization have been primarily influenced by the studies in large cities. With the dominance of small cities expected to lead future urbanization globally, it is important to study smaller cities. In 2018, for instance, about $26.5 \%$ of the world inhabitant lived in cities with less than 0.5 million dwellers [23]. Similarly, from 2018 to 2030 , the number of cities with 0.5 million people or more is expected to increase by $23 \%$ in Asia and by $57 \%$ in Africa [23]. This scenario has a likelihood to cause fast urban expansion and amplify the stress on neighboring ecosystems. Hence, understanding the rapid urbanization and its implication, the dynamics of landscape patterns in the small cities can play a notable role in sustainable development especially considering the issues of ecosystem services and changing climate while offering common services and infrastructures for the growing population. In addition, such studies can help guidance concerning the actions that could slow down the negative impacts of urbanization that have already been witnessed for large cities.

By analyzing the urban landscape structures, the landscape heterogeneity, and the impact of different ecological services associated with cities can be ascertained [24,25]. Landscape metrics can be useful to reveal the general circumstances of the urban landscape pattern $[10,26,27]$, triggers of urban land use, and change analysis [11,14,15,21,28-32], as well as assessing the projected future urban spatial form [13]. Landscape metrics studies are also primarily applied to detect the relationship between landscape patterns and land surface temperature [33-36]. Thus, the studies on urban land use dynamics have not only presented temporal and spatial characteristics of urban development but have also offered evidence to address severe ecological and environmental concerns threatening urban ecosystems [37-39]. Referring to the land use maps and changes, policymakers, and urban planners can often identify measures to minimize adverse effects related to urban growth.

This study concerns urban expansion in Ethiopia. The urban growth in Ethiopia, and likely in many African cities, is generally characterized by a lack of adequate planning or lack of implementation of plans, resulting in cities that often have a shortage of necessary infrastructure and services [40-42]. The absence of urban planning or enforcement may also have contributed to fragmented urban landscape patterns along major roadways to its rural fringes especially in the regional cities. Since the past couple of decades, regional cities in Ethiopia have grown faster than the capital city, Addis Ababa [43]. This feature can likely be explained considering the national economic development [44] and urban improvement policies [45] that fostered the rapid urban expansion in secondary and tertiary cities.

Some studies have explored urban expansion in Ethiopia [15,19,42,46,47], primarily focusing on the analysis of urban growth and urban land changes in the regional or capital cities. However, the literature on the trend of urban spatial growth and its influences on other natural landscape configurations is quite limited with regards to small cities and towns. Additionally, there is a general lack of studies considering the detailed spatial and temporal urban landscape patterns and urban spatial growth trends analysis at different distances from the town center. 
The Oromia Special Zone surrounding Finfinnee/Addis Ababa is one of the most rapidly growing towns in Ethiopia. This Zone in general and the towns, in particular, have experienced a high rate of urban expansion. The towns experienced rapid urbanization as an industrial and residential hub. The expansion was propelled by the large migration from various rural areas and from Addis Ababa to the surrounding towns. The Special Zone with is proximity to Addis Ababa, the national capital city also likely contributed to the migrant influx. As a result, the peri-urbanization development continues and the area is also highly susceptible to land grabbing [48]. The spatial growth of the towns in the Special Zone presents an excellent scenario for studying rapid expansion from the inner to the outskirts and from the periphery to the centers of towns. Such trends also reflect the characteristics of most satellite cities globally in general and for the large African cities, in particular.

Accordingly, in this study, we postulate that investigating and comparing the detailed urban landscape structures and dynamics of the towns is important for understanding the historical changes of urban regions, and for guiding future sustainable development. In particular, this study addresses the following questions: Are the urbanization processes in small cities similar to the large and medium-sized cities? In what way do smaller cities affect landscape structures, and what are the possible drivers for urbanization? These questions are addressed by focusing on six towns of the Oromia Special Zone surrounding Finfinnee, Ethiopia. The assessment included the dynamics of landscape structures, the trend in urban growth, the urban spatial patterns in multi-buffer rings analysis, and its possible drivers, from the year 1987 to 2019, as discussed in the following section.

\section{Materials and Methods}

\subsection{Study Area}

The study was conducted in the six towns: Burayu, Sebeta, Sululta, Lege-Tafo, Gelan, and Dukem, in the Special Zone surrounding Finfinnee, Oromia regional state, Ethiopia (Figure 1). Finfinnee, which established in the late 18th century, is the capital city of the country as well as the regional state of Oromia. Since its foundation, it has expanded rapidly by conjoining the surrounding rural areas, which is outside of its legal administrative boundary. Within the past 30 years, the physical growth of the city tripled itself, from $99 \mathrm{~km}^{2}$ area in 1987 to $284 \mathrm{~km}^{2}$ in 2017 [15]. Recognizing the need to contain such a sprawl, Oromia regional state created the Oromia Special Zone surrounding Finfinnee in 2008 [48]. The Special Zone consists of six towns mentioned above having self-administrative powers. Their geographical locations, climate, and socio-economics conditions are summarized in Table 1 and Figure 1. All selected towns, except Dukem, share common boundaries with Addis Ababa, the national capital city. The population of each town ranged from 27,600 (for Lege-Tafo) to 167,127 (for Sebeta) in 2017 (Table 1). The total area of each city is less than $100 \mathrm{~km}^{2}$. The elevation ranges from $2976 \mathrm{~m}$ (in Burayu) to $2059 \mathrm{~m}$ (in Dukem) above sea level (Figure 1). The mean annual temperature ranges from $14.5^{\circ} \mathrm{C}$ to $19.5^{\circ} \mathrm{C}$ (Table 1$)$.

Table 1. Geographical position, population, and climate of the six cities.

\begin{tabular}{ccccc}
\hline Town & Latitude - Longitude & $\begin{array}{c}\text { Population } \\
(\mathbf{2 0 1 7})^{\mathbf{a}}\end{array}$ & $\begin{array}{c}\text { Elevation } \\
\left(\mathbf{m} \text {.a.s.1. }{ }^{\mathbf{b}}\right)\end{array}$ & $\begin{array}{c}\text { Mean-Temperature } \\
\left(\mathbf{C}^{\circ}\right)^{\mathbf{c}}\end{array}$ \\
\hline Burayu & $9^{\circ} 01^{\prime} 00^{\prime \prime}-9^{\circ} 06^{\prime} 00^{\prime \prime} \mathrm{N}, 38^{\circ} 35^{\prime} 30^{\prime \prime}-38^{\circ} 42^{\prime} 00^{\prime \prime} \mathrm{E}$ & 92,331 & 2712 & 14.7 \\
\hline Sululta & $9^{\circ} 06^{\prime} 00^{\prime \prime}-9^{\circ} 12^{\prime} 00^{\prime \prime} \mathrm{N}, 38^{\circ} 42^{\prime} 00^{\prime \prime}-38^{\circ} 47^{\prime} 00^{\prime \prime} \mathrm{E}$ & 55,358 & 2730 & 15 \\
\hline Lege-Tafo & $9^{\circ} 01^{\prime} 30^{\prime \prime}-9^{\circ} 07^{\prime} 30^{\prime \prime} \mathrm{N}, 38^{\circ} 51^{\prime} 00^{\prime \prime}-38^{\circ} 57^{\prime} 00^{\prime \prime} \mathrm{E}$ & 27,636 & 2453 & 15.6 \\
\hline Sebeta & $8^{\circ} 52^{\prime} 30^{\prime \prime}-8^{\circ} 59^{\prime} 30^{\prime \prime} \mathrm{N}, 38^{\circ} 34^{\prime} 00^{\prime \prime}-38^{\circ} 42^{\prime} 30^{\prime \prime} \mathrm{E}$ & 167,127 & 2346 & 17 \\
\hline Gelan & $8^{\circ} 47^{\prime} 30^{\prime \prime}-8^{\circ} 53^{\prime} 00^{\prime \prime} \mathrm{N}, 38^{\circ} 47^{\prime} 00^{\prime \prime}-38^{\circ} 53^{\prime} 00^{\prime \prime} \mathrm{E}$ & 59,817 & 2215 & 18.5 \\
\hline Dukem & $8^{\circ} 45^{\prime} 30^{\prime \prime}-8^{\circ} 50^{\prime} 30^{\prime \prime} \mathrm{N}, 38^{\circ} 51^{\prime} 30^{\prime \prime}-38^{\circ} 56^{\prime} 00^{\prime \prime} \mathrm{E}$ & 40,180 & 2059 & 19.5 \\
\hline
\end{tabular}

a estimated from the Central Statistical Agency (CSA) and Bureau of Oromia Finance and Economic Development.

${ }^{b}$ Meter above sea level. ${ }^{c}$ Source: Ethiopia Meteorological Agency. 


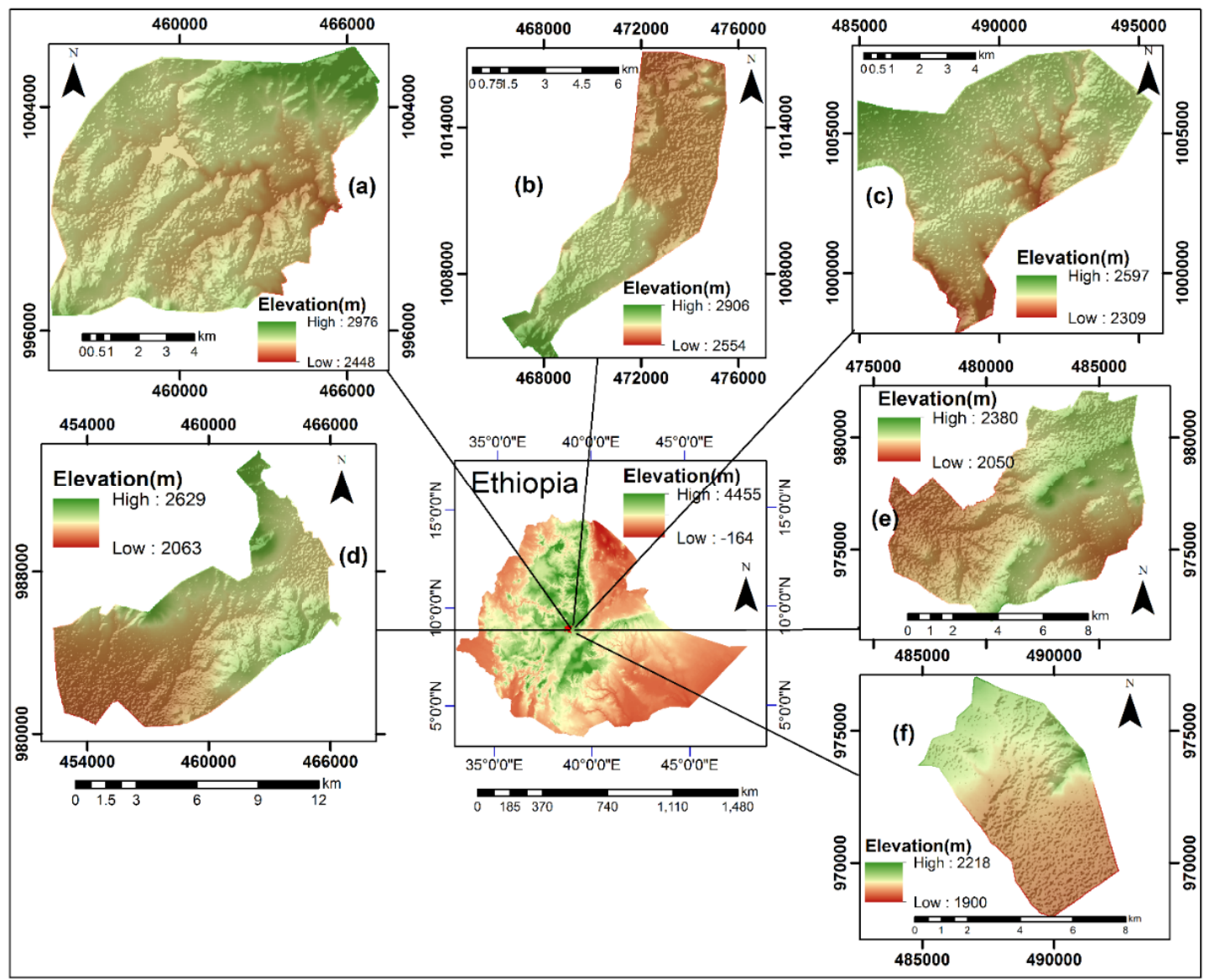

Figure 1. Map of the study area showing: (a) Burayu, (b) Sululta, (c) Lege-Tafo, (d) Sebeta, (e) Gelan, and (f) Dukem.

\subsection{Remote Sensing Data}

Cloud-free, Landsat Thematic Mapper (TM) and Landsat 8 (OLI) images were used in this assessment. The Landsat images were acquired on the 09, 10, and 01 of February 1987, 1999, and 2019, respectively. All Landsat images (path 168, row 54) were obtained from the United States Geological Survey and Global Land Cover Facility websites. Image classification was done using ENVI version 5.3, with accuracy assessments using ERDAS Imagine version 2014, and ArcGIS version 10.4 to perform the image data processing which includes projection correction and producing maps. The land cover types were classified into five categories: (1) built-up area; (2) agricultural land; (3) vegetation cover; (4) water body; and (5) grassland. They were classified based on knowledge of the areas, the spectral responses of features on the Landsat images, the use of higher spatial resolution imagery, and visual analysis of different remote sensing products. Descriptions of these five categories are summarized in Table 2. Supervised image classification was done using the Support Vector Machine (SVM) Classifier algorithm which is widely applied for the urban area analysis $[26,49]$.

Furthermore, Google Earth Proß(GE) was applied to verify the accuracy of the classified satellite images [50]. The Google Earth images acquired in 2019 were used to verify the accuracy of the classified results. Due to the lack of high-resolution historical satellite images in the study site, the classification accuracy results of 1987 and 1999 were validated by generating more than 140 random points for each land use/cover (LULC) class from the areas where the land cover remained unchanged. 
Table 2. Land use/cover (LULC) classes and descriptions.

\begin{tabular}{|c|c|}
\hline LULC Classes & Description \\
\hline Urban/built-up areas: & $\begin{array}{c}\text { Residential, commercial, industrial, transportation, services, communication, } \\
\text { and utilities. }\end{array}$ \\
\hline Agricultural areas: & Cropland, horticultural farms, irrigation farms, and other agronomic regions. \\
\hline Vegetation cover: & $\begin{array}{l}\text { Land covered by forest patches, woodland, shrubs, scattered trees mixed with grass, } \\
\text { and perennial crops. }\end{array}$ \\
\hline Water bodies: & Lakes, rivers, and ponds. \\
\hline Grass: & $\begin{array}{l}\text { Herbaceous cover with a minor proportion of trees and shrubs, lawns, parks, } \\
\text { and grasses mixed with shrubs and scrubs. }\end{array}$ \\
\hline
\end{tabular}

\subsection{Analysis of Land Use/Cover and Urban Expansion}

Figure 2 shows the general workflow for urban landscape analysis adopted in the study. Generally, this technical workflow presents four major activities: (1) Remote sensing data and processing, (2) classification and validation of the classified images, (3) landscape structure analysis, and (4) spatial patterns of urban growth analysis.

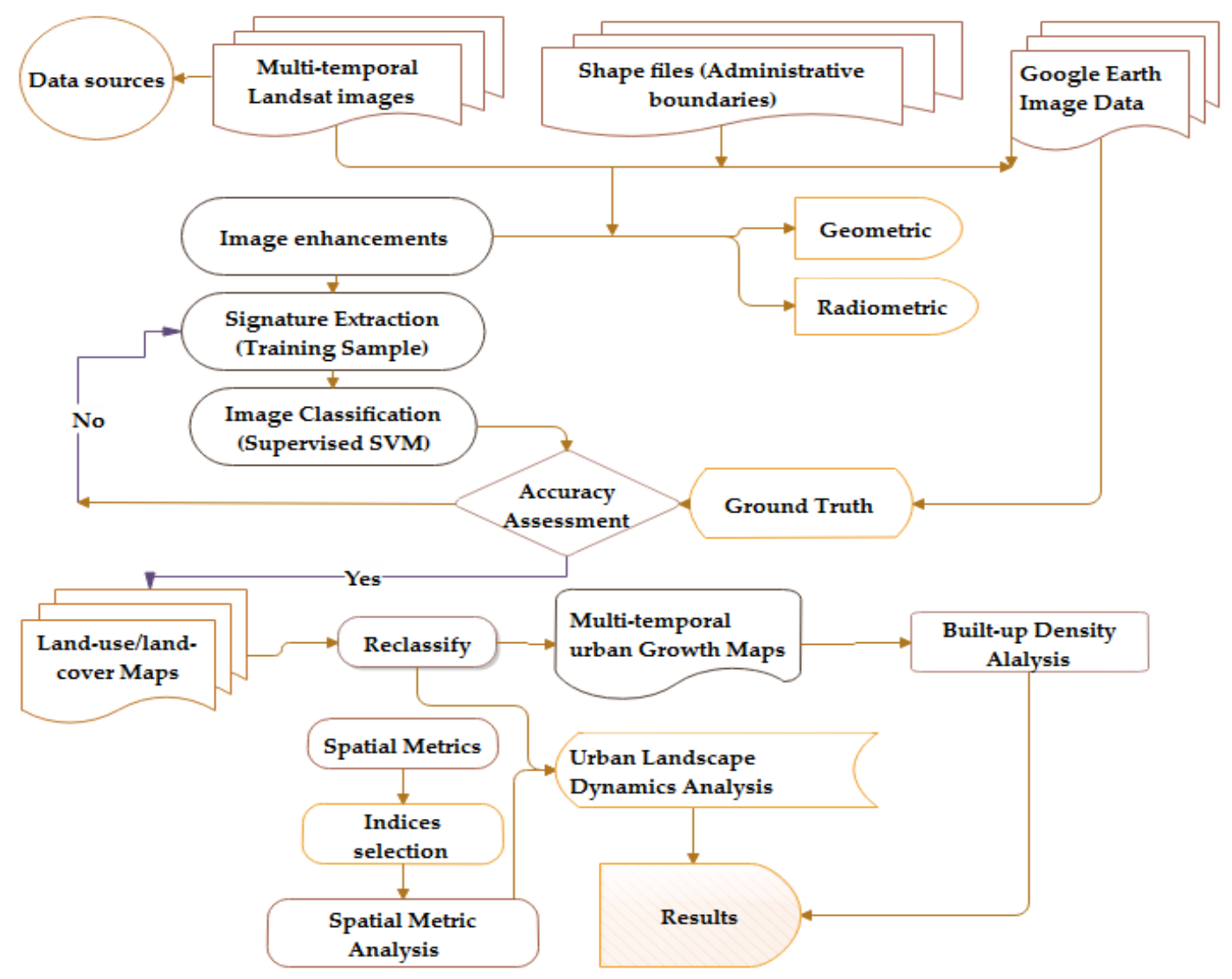

Figure 2. The general workflow for urban landscape analysis in the study.

Expansion percentage of change (PC), annual increase (AI), and annual expansion rate (AER) indicators were employed to analyze the LULC changes and calculate the area and rate of annual urban expansion. The PC indicator is used to calculate the proportion of LULC changes, while the AI is employed to reflect the speed of urban areas growth across the study periods. The AER index is applied to show the rate of urban land expansion within each study period, as shown in Equations (1-3), which follows $[15,19,51]$, with some modification. 


$$
\begin{gathered}
P C=100 \% \times \frac{A_{e}-A_{i}}{A_{i}} \\
A I=\frac{U_{e}-U_{i}}{T} \\
A E R=100 \% \times\left[\left(\frac{U_{e}}{U_{i}}\right)^{\frac{1}{T}}-1\right]
\end{gathered}
$$

where, $A_{i}$ and $A_{e}$ represent the area coverage of each land-use land-cover type $\left(\mathrm{km}^{2}\right)$ at the initial and end of the monitoring period, respectively. Positive percentage values suggest an increase whereas negative values imply a decrease in area coverage. The $U_{i}$ and $U_{e}$ represent the same type of built-up area at the initial and end of the monitoring period, respectively, and $T$ is the period from the time $i$ to $e$. When $T$ is 1 year, the AER is the annual built-up expansion rate.

\subsection{Landscape Metrics Analysis}

Five landscape metrics were selected for studying the landscape changes, namely the percentage of the urban area (UA), the number of patches (NP), edge density (ED), mean nearest neighbor distance (MNN), and mean patch size (MPS) (Table 3 [52]). These metrics were selected by considering: (i) relevance to the study objectives; (ii) significance in terms of theory and practice; (iii) minimal redundancy; and (iv) ease in calculating and interpreting the results $[33,53,54]$ to characterize landscape dynamics due to the effects of urbanization. The UA landscape metrics quantify the spatial composition while the last four metrics calculate urban spatial configuration.

In addition, the built-up density (BD) analysis has been employed to explore the compactness of the newly growing urban condition using Equation (4), following [25,49]. The BD analysis provides information regarding whether the new urban growth was high or low density, which identifies the occurrence of urban sprawl. Patch Analyst version 5.2 (Fragstats Interface) extension in ArcGIS with the 8-neighbor rule was employed to compute the value of the landscape metrics [55]. The study further explored the detailed landscape alterations across the concentric distances. A series of concentric buffer circles within every one-kilometer distance was generated. In the concentric rings, the urban-rural gradient appeared to be more effective in illustrating the landscape pattern due to the unchanged sampling size [56,57]. Finally, the BD values within each buffer circle were calculated as:

$$
B D=\frac{\text { Urban area per buffer ring }}{\text { Total buffer area of ring }} \times 100 \%
$$

\begin{tabular}{|c|c|c|c|}
\hline Landscape Metrics & Abbreviation & Unit & Description \\
\hline Urban land percentage & UA & $\%$ & $\begin{array}{l}\text { The proportion of the landscape occupied by } \\
\text { urban patch in the buffers }\end{array}$ \\
\hline Number of patches & NP & number & $\begin{array}{l}\text { The total number of urban patches in the } \\
\text { landscape }\end{array}$ \\
\hline Mean patch size & MPS & ha & Mean urban patch size \\
\hline Edge density & ED & $\mathrm{m} / \mathrm{ha}$ & $\begin{array}{c}\text { The total length of all edge segments per hectare } \\
\text { urban patches }\end{array}$ \\
\hline $\begin{array}{c}\text { Mean nearest neighbor } \\
\text { distance }\end{array}$ & $\mathrm{MNN}$ & $\mathrm{m}$ & Urban patch edge-to-edge distance \\
\hline
\end{tabular}

where BD represents the built-up density. The value of BD lies between 0 and 1, with 0 representing the low density, whereas 1 signifying high density.

Table 3. Selected landscape metrics adopted from McGarigal [52]. 


\section{Results}

\subsection{Accuracy Assessment}

Table 4 summarizes the LULC classification accuracy assessment results. Overall classification accuracy was found to be $87.9,88.2$, and 89.4 percent for the year 1897, 1999, and 2019, respectively. The kappa coefficient values of the LULC classification were about $0.85-0.88$. These results indicate that the classified maps' truthfulness was greater than $87 \%$. Thus, the image processing method implemented in this study was effective in producing compatible LULC data over time.

Table 4. Accuracy assessment of the classified images by study periods (in percent).

\begin{tabular}{|c|c|c|c|c|c|c|}
\hline \multirow[b]{2}{*}{ Class } & \multicolumn{2}{|c|}{1987} & \multicolumn{2}{|c|}{1999} & \multicolumn{2}{|c|}{2019} \\
\hline & $\begin{array}{l}\text { Producers } \\
\text { Accuracy }\end{array}$ & $\begin{array}{c}\text { Users } \\
\text { Accuracy }\end{array}$ & $\begin{array}{l}\text { Producers } \\
\text { Accuracy }\end{array}$ & $\begin{array}{c}\text { Users } \\
\text { Accuracy }\end{array}$ & $\begin{array}{l}\text { Producers } \\
\text { Accuracy }\end{array}$ & $\begin{array}{c}\text { Users } \\
\text { Accuracy }\end{array}$ \\
\hline Agricultural land & 86.76 & 77.63 & 79.14 & 84.87 & 82.72 & 88.86 \\
\hline Built-up area & 84.51 & 91.60 & 89.39 & 87.41 & 92.44 & 84.18 \\
\hline Vegetation & 88.46 & 85.82 & 90.48 & 92.12 & 91.15 & 84.16 \\
\hline Water body & 100.00 & 100.00 & 99.23 & 100.00 & 99.50 & 100.00 \\
\hline Grassland & 80.00 & 85.50 & 84.13 & 76.81 & 82.80 & 89.87 \\
\hline Overall Accuracy & \multicolumn{2}{|c|}{87.88} & \multicolumn{2}{|c|}{88.18} & \multicolumn{2}{|c|}{89.4} \\
\hline Overall Kappa & \multicolumn{2}{|c|}{0.85} & \multicolumn{2}{|c|}{0.85} & \multicolumn{2}{|c|}{0.88} \\
\hline
\end{tabular}

\subsection{Urban Expansion and Its Response to Other Natural Land Cover Patterns}

Figures 3 and 4 display the overall changes in the land use pattern of the study towns over the 32 years study period. Each of the cities witnessed rapid and substantial changes in their land-use configuration. In 1987, the built-up areas were in a relatively small region and concentrated around the city centers. The green area (vegetation and grass) was the largest land-use type in towns of Burayu, Sululta, and Lege-Tafo (Figure 3a,c and Figure 4a), whereas, agriculture was the predominant one in Sebeta, Gelan, and Dukem (Figures 3b and 4c,d). In 1999, the built-up areas stretched out gradually and significantly increased while replacing the vegetated and agriculture area through 2019. Such alterations, caused by urbanization, have notably affected vegetation coverage and agricultural lands in the areas.

As shown in Tables 5 and 6, the towns under the study area experienced large changes in LULC over the 32-year study period. The highest loss of green areas occurred during the 1999-2019 period in all towns, where the vegetation area increased by $4.5 \%$ and grass class increased by $120.1 \%$, except for Gelan (Table 5). Increase in the agricultural regions was noted in all towns except Dukem from the year 1987 to 1999; however, the values were significantly decreased from 1999 to 2019. Conversely, the area of urban land showed a significant increase in all towns during the last decade, in which the highest expansion was observed in Lege-Tafo (13,434.8\%) and smallest in Sebeta (1306.9\%) (Table 6). In general, due to urbanization, $41 \mathrm{~km}^{2}(-21.7 \%)$ area of agricultural land, shifted into urban areas, whereas, a loss of $36.9 \mathrm{~km}^{2}(-45.3 \%)$ area of vegetation cover and $67.84 \mathrm{~km}^{2}(-63 \%)$ area of grasslands was found (Tables 5 and 6). The area occupied by the water bodies was relatively stable and showed no changes during the entire study periods (Table 5). To generalize, the total urban area of all towns in the study increased to $127.63 \mathrm{~km}^{2}(+3422 \%)$ in 2019 from the baseline area of $3.73 \mathrm{~km}^{2}$ in 1987, leading to a continuous fragmentation and degeneration of natural components of the ecological network. 


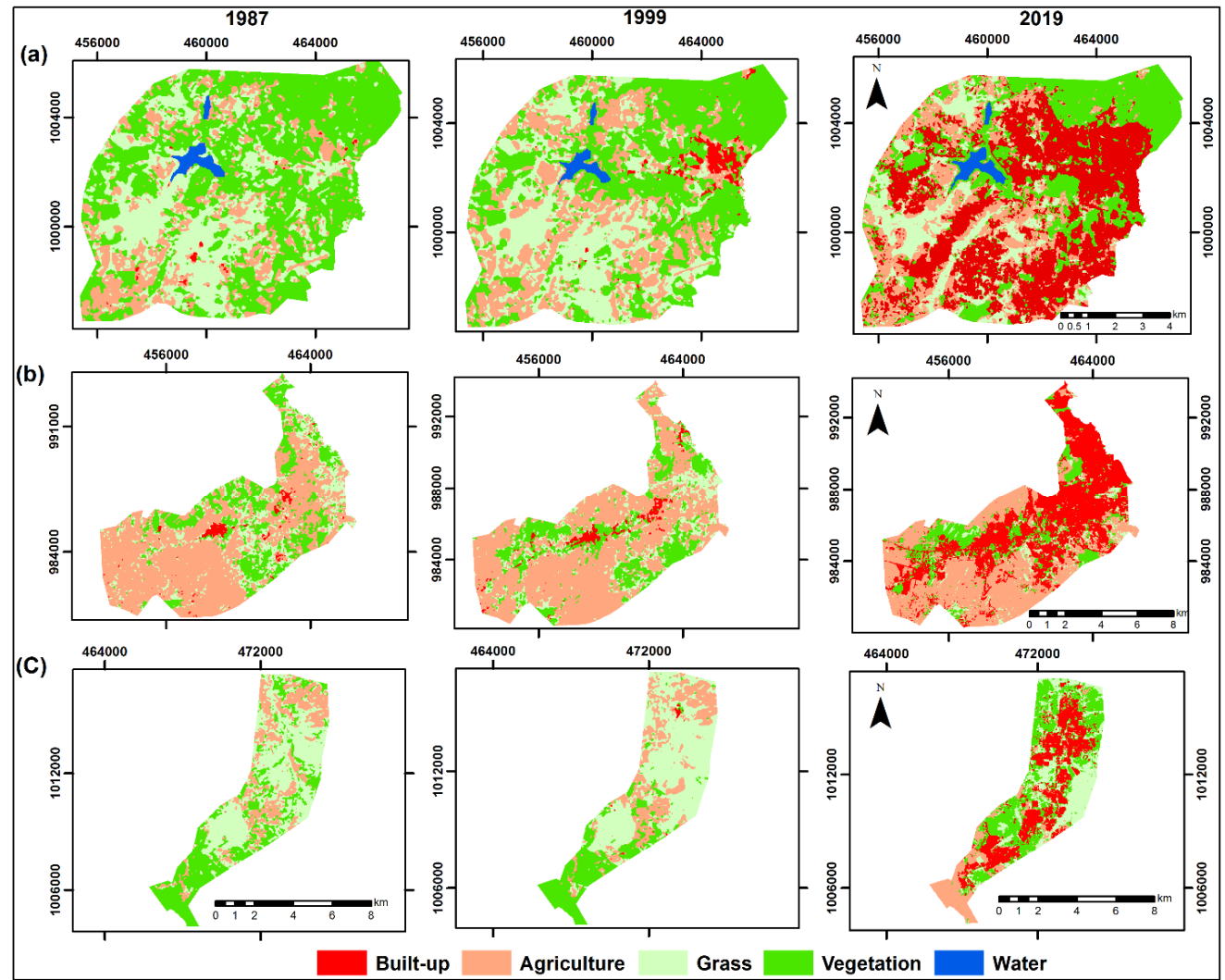

Figure 3. Land-cover maps of (a) Burayu, (b) Sebeta, and (c) Sululta 1987-2019.

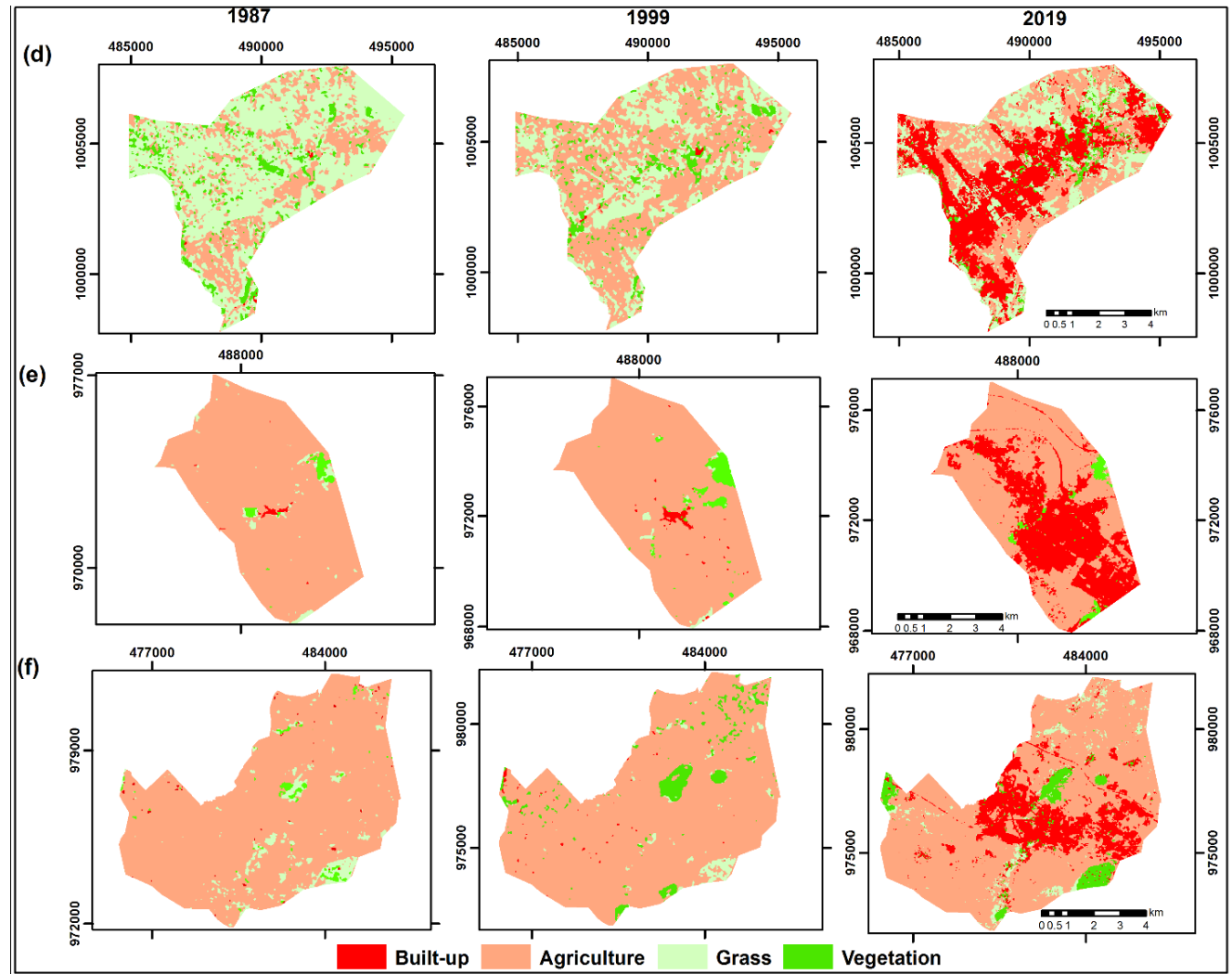

Figure 4. Land-use land-cover maps of (d) Lege-Tafo, (e) Dukem, and (f) Gelan 1987-2019. 
Table 5. Land-use land-cover (LULC) area in $\mathrm{km}^{2}$ between 1987 and 2019.

\begin{tabular}{|c|c|c|c|c|c|c|c|c|c|c|c|c|c|c|c|c|c|c|c|}
\hline \multirow{2}{*}{ Classes } & \multicolumn{3}{|c|}{ Burayu } & \multicolumn{3}{|c|}{ Sebeta } & \multicolumn{3}{|c|}{ Lege-Tafo } & \multicolumn{3}{|c|}{ Sululta } & \multicolumn{3}{|c|}{ Dekem } & \multicolumn{3}{|c|}{ Gelan } & \multirow{2}{*}{$\begin{array}{c}\begin{array}{c}\text { Total } \\
\text { Changes }\end{array} \\
\text { 1987-2019 }\end{array}$} \\
\hline & 1987 & 1999 & 2019 & 1987 & 1999 & 2019 & 1987 & 1999 & 2019 & 1987 & 1999 & 2019 & 1987 & 1999 & 2019 & 1987 & 1999 & 2019 & \\
\hline Built-up & 1.25 & 1.88 & 32.34 & 1.66 & 2.45 & 34.50 & 0.09 & 0.14 & 18.88 & 0.21 & 0.29 & 12.06 & 0.39 & 0.42 & 21.38 & 0.13 & 0.24 & 12.20 & 127.63 \\
\hline Agriculture & 15.73 & 22.89 & 17.47 & 50.50 & 52.27 & 33.88 & 14.39 & 29.29 & 23.61 & 10.24 & 10.75 & 8.88 & 34.36 & 34.02 & 13.87 & 63.51 & 63.58 & 50.03 & -41.00 \\
\hline Vegetation & 41.83 & 34.06 & 21.11 & 17.79 & 16.90 & 10.91 & 4.29 & 3.35 & 1.99 & 13.31 & 9.36 & 6.42 & 0.57 & 1.30 & 0.83 & 3.72 & 3.21 & 3.36 & -36.90 \\
\hline Grass & 41.05 & 23.44 & 11.18 & 13.97 & 12.28 & 4.62 & 31.42 & 17.41 & 5.70 & 19.52 & 22.78 & 15.61 & 0.82 & 0.40 & 0.06 & 0.88 & 1.21 & 2.65 & -67.84 \\
\hline Water & 1.06 & 1.06 & 1.06 & - & - & - & - & - & - & - & - & - & - & - & - & - & - & - & - \\
\hline Total & 83.34 & 83.34 & 83.34 & 103.78 & 103.78 & 103.78 & 50.18 & 50.18 & 50.18 & 62.85 & 62.85 & 62.85 & 36.14 & 36.14 & 36.14 & 68.24 & 68.24 & 68.24 & \\
\hline
\end{tabular}

Table 6. Percentage of LULC class changes for 1987 to 2019.

\begin{tabular}{|c|c|c|c|c|c|c|c|c|c|c|c|c|c|}
\hline \multirow{2}{*}{ Classes } & \multicolumn{2}{|c|}{ Burayu } & \multicolumn{2}{|c|}{ Sebeta } & \multicolumn{2}{|c|}{ Lege-Tafo } & \multicolumn{2}{|c|}{ Sululta } & \multicolumn{2}{|c|}{ Dukem } & \multicolumn{2}{|c|}{ Gelan } & \multirow{2}{*}{$\begin{array}{c}\text { Total } \\
1987-2019\end{array}$} \\
\hline & 1987-1999 & 1999-2019 & 1987-1999 & 1999-2019 & 1987-1999 & 1999-2019 & 1987-2019 & 1999-2019 & 1987-1999 & 1999-2019 & 1987-1999 & 1999-2019 & \\
\hline Built-up & 50.5 & 1616.9 & 47.6 & 1306.9 & 59.8 & 13434.8 & 40.3 & 3958.3 & 0.3 & 5390.7 & 90.5 & 2153.7 & 3421.7 \\
\hline Agriculture & 45.5 & -23.7 & 3.5 & -35.2 & 103.6 & -19.4 & 5.0 & 17.34 & -2.4 & -58.6 & 0.1 & -20.9 & -21.7 \\
\hline Vegetation & -18.6 & -38.0 & -5.0 & -35.4 & -22.0 & -40.6 & -29.7 & -31.4 & 11.3 & -81.4 & -13.7 & 4.5 & -45.3 \\
\hline Grass & -42.9 & -52.3 & -12.0 & -62.4 & -44.6 & -67.2 & 16.7 & -31.47 & -4.0 & -42.0 & 36.8 & 120.1 & -63.0 \\
\hline Water & 0.0 & 0.0 & & & & & & & & & & & \\
\hline
\end{tabular}




\subsection{Magnitude and Rates of Urban Expansion}

The urban expansion maps for the six towns across the study periods are displayed in Table 7. With the exception of Burayu and Gelan, the built-up area was small and mainly situated in the central parts of each town in the year 1987, whereas Burayu exhibited the scattered forms in the eastern and south-eastern direction parts of the town. Gelan was rural and had a small and dispersed built-up area during the same time period. The expansion of the built-up area class is evident in the 2019 map. The evaluation of class statistics displays that there has been a noticeable urban area expansion within a span of 32 years.

As shown in Table 7, all towns experienced a fast increase of built-up areas, resulting in dramatic transformations in spatial patterns from 1987 to 2019. The highest and the lowest AI occurred from 1999 to 2019 and between the period 1987 and 1999, respectively (Table 7). Sebeta, which has the biggest city, had the highest AI (103 ha) during the year 1987-2017. However, the town experienced the least annual expansion rate $(61.8 \%$ ) during the same period (Table 7), whereas the smallest town (Lege-Tafo) experienced the highest AER (652.4\%). This indicated that small towns have higher expansion rates. Other towns showed rates of annual expansion ranging from $77.7 \%$ (Burayu) to $290.1 \%$ (Dukem).

More generally, the total annual increment was 398.9 ha/year for the study period from 1987 to 2019. Thus, annually on average about 67 ha of non-urban land from each city was converted to built-up land per annum for the past 32-years. From 1987 to 1999, built-up areas of the Special Zone increased by about 14.26 ha per year. More recently, between the years 1999 and 2019, the study site annually shows 629.7 ha of the non-urban area (Table 7). Thus, the Special Zone transformed about 630 ha of natural land covers per annum during the second study period. Indeed, if the trend continues, it would be equivalent to losing 1.73 ha of agro-vegetation areas per day.

Table 7. Annual intensity (AI) and annual expansion rates (AER) of the built-up area from 1987 to 2019.

\begin{tabular}{ccccccc}
\hline \multirow{2}{*}{ Town } & \multicolumn{3}{c}{ AI(ha/year) } & \multicolumn{3}{c}{ Urban Expansion Rate (AER) ( \% per year ) } \\
\cline { 2 - 7 } & $\mathbf{1 9 8 7 - 1 9 9 9}$ & $\mathbf{1 9 9 9 - 2 0 1 9}$ & $\mathbf{1 9 8 7 - 2 0 1 9}$ & $\mathbf{1 9 8 7 - 1 9 9 9}$ & $\mathbf{1 9 9 9 - 2 0 1 9}$ & $\mathbf{1 9 8 7 - 2 0 1 9}$ \\
\hline Burayu & 5.27 & 152.30 & 97.15 & 4.20 & 81.01 & 77.73 \\
\hline Sebeta & 6.59 & 160.25 & 102.63 & 3.97 & 65.41 & 61.82 \\
\hline Lege-Tafo & 0.44 & 93.70 & 58.73 & 4.63 & 669.29 & 652.43 \\
\hline Sululta & 0.71 & 58.85 & 37.02 & 3.17 & 202.93 & 176.34 \\
\hline Gelan & 0.29 & 104.80 & 65.60 & 0.64 & 249.52 & 168.19 \\
\hline Dukem & 0.96 & 59.80 & 37.72 & 7.05 & 249.17 & 290.14 \\
\hline Total & $\mathbf{1 4 . 2 6}$ & $\mathbf{6 2 9 . 7 0}$ & $\mathbf{3 9 8 . 8 5}$ & $\mathbf{3 . 7 8}$ & $\mathbf{1 1 6 . 1 8}$ & $\mathbf{1 0 6 . 9 3}$ \\
\hline
\end{tabular}

\subsection{Dynamic Change of Landscape Pattern During 1987-2019}

As shown in Figure 5a-c, the analysis of urban fragmentation metrics calculated from the LULC maps at the urban scale revealed significant changes throughout the study period. The landscape of all towns became more fragmented and complex in pattern as indicated by the constant increase in the $\mathrm{NP}, \mathrm{ED}$, and decrease in MPS values. However, the immense increase of fragmentation observed from 1999 to 2019 is a consequence of intensive sprawling processes. 

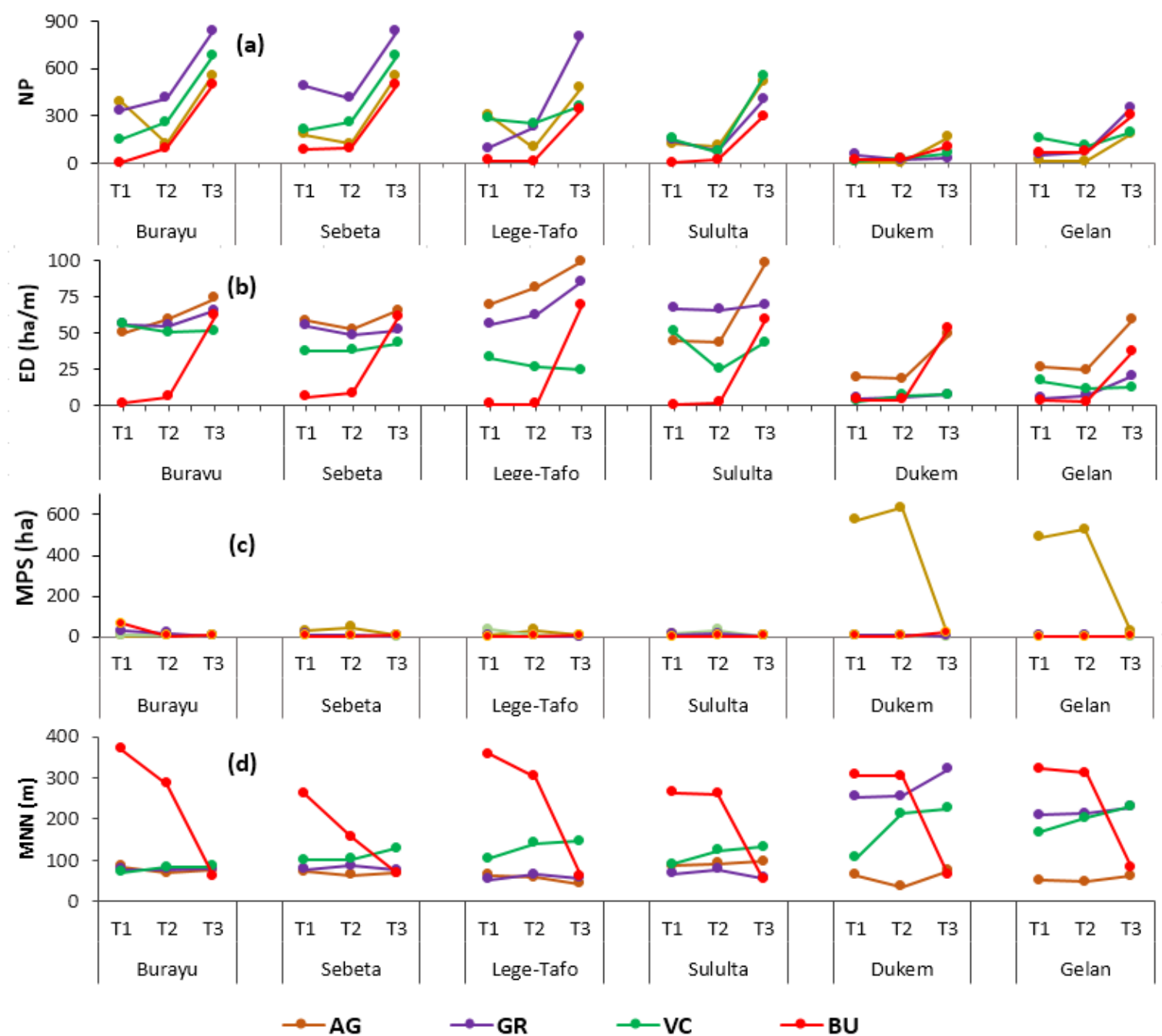

Figure 5. Spatial metrics at city scale: (a) number of patches, (b) edge density $(\mathrm{m} / \mathrm{ha})$, (c) mean patches size (ha), and (d) mean nearest neighbor distance $(\mathbf{m}) . \mathrm{AG}=$ Agriculture, GR = Grass, VC = Vegetation, and BU = Built-up; T1 = 1987, T2 = 1999, and T3 =2019.

Between 1987 and 1999, the NP shows a gradually increasing trend except for agriculture across the towns, and vegetation in Sebeta, Lege-Tafo, and Sululta (Figure 5a). The results of ED also follow similar trends as of NP over the periods except for Burayu and Lege-Tafo in which the gradual increasing patterns of agriculture were recorded. In contrast, the NP and ED values of built-up, vegetation, agricultural, and grass showed significantly increased during the second study period (1999-2019) in whole towns. At the same time, the densification of the urban core is confirmed by a decrease in MNN over the periods (Figure 5d). For instance, it is marked that in the year 1987, the urban patches of Burayu, Gelan, and Lege-Tafo towns were relatively more distant $(370 \mathrm{~m}, 312 \mathrm{~m}$, and $302 \mathrm{~m}$, respectively) from each other. In 1999, the average distance reduced persistently and was the lowest in 2019 for Burayu, Gelan, and Lege-Tafo towns: 59 m, $80 \mathrm{~m}, 62 \mathrm{~m}$, respectively. Thus, the urban core is becoming compact due to the development of new built-up patches near and between existing built-patches. In contrast, connectivity of the other LULC patches revealed decreasing trends, suggesting that the natural landscape has become more fragmented across each of the cities over the last 32 years.

In comparison, over the entire study period, the highest fragmented vegetation patches were observed in Burayu and Sebeta, as evidenced by the near-continuous increase in the NP values. Furthermore, the agriculture patches were considerably disconnected in Gelan and Dukem, as 
indicated by significantly decreased MPS. In 1987, the MPS in Dukem was 486 ha while Gelan had 634 ha (Figure 5). These numbers significantly declined to 27 ha and 8.5 ha, respectively, in 2019 . This implies that the towns grew at the expense of farmlands. In general, the landscape metrics analysis indicated that all the studied towns of the Special Zone surrounding Finfinnee had a more fragmented and complicated urban landscape due to the scattered nature of urban growth during these respective periods.

\subsection{Built-Up Density Analysis}

Figure 6 shows the spatial patterns of the built-up density of each town. Based on the BD values, Sululta and Gelan revealed a similar trend. For both these towns, between the years 1987 and 2019, the $\mathrm{BD}$ values steadily increased within 1-2 $\mathrm{km}$ distance and the decreasing trend was seen from $2 \mathrm{~km}$ onwards (Figure $6 \mathrm{c}, \mathrm{f}$ ). That is, dense built-up and reduced outskirts of the towns are evident. An inverse trend was observed in Burayu and Sebeta. The BD values decreased within $1-5 \mathrm{~km}$ in Burayu and 1-6 km in Sebeta from their downtowns and increased at fringes of their towns (Figure 6a,b). This indicates that the newly developed areas on the outskirts are relatively dense. The BD results of Lege-Tafo and Dukem showed that the outward moving of the reducing trend from a distance of 1 to $6 \mathrm{~km}$. The BD values increased within $6-8 \mathrm{~km}$ in Lege-Tafo, and finally, the decreasing trend was observed from the distance $8 \mathrm{~km}$ (Figure $6 \mathrm{~d}$,e). In general, the BD analysis showed that over the past 32 years, except for Burayu and Dukem, the built-up density revealed a complex distribution of clusters growing in patches across each of the towns.
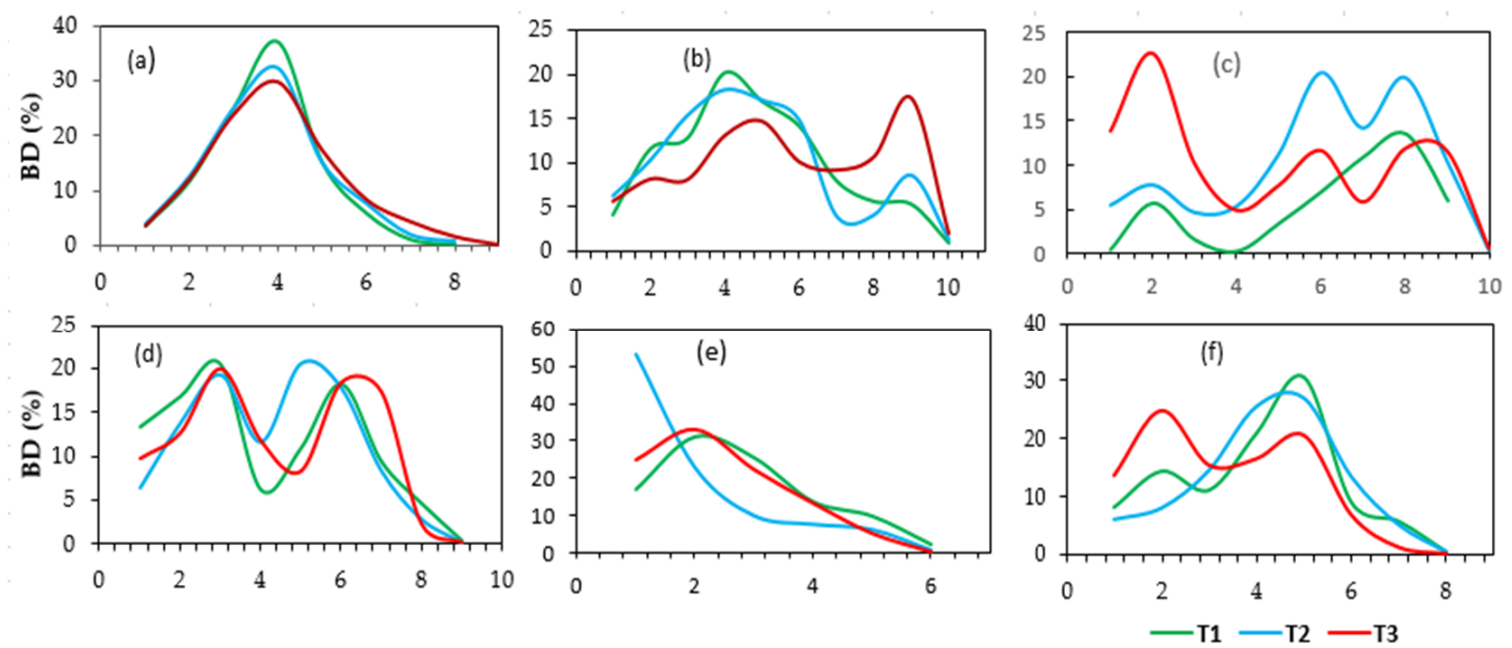

Figure 6. The built-up density of each town at different distances, for T1, T2, and T3 corresponding to (a) Burayu, (b) Sebeta, (c) Sululta (d) Lege-Tafo, (e) Dukem, and (f) Gelan.

\section{Discussion}

The study provides clear evidence that the urban expansion rate of towns and small cities can be very high (and larger than those reported for large cities in the literature). Most of the large cities are growing at a rate of less than 10 percent per annum. The annual expansion rate of Addis Ababa (Ethiopia), Tshwane (South Africa), Beijing (China), and Kolkata metropolitan (India) were, for example, $3.4 \%, 3.52 \%, 3.46 \%$, and 5.4\%, respectively between the year 1984 and 2017 [11,15,58,59]. This value, however, can exceed $100 \%$ in the towns. In this study, for instance, the annual spatial growth rates of Lege-Tafo was $652.43 \%$ (see Table 7). The landcover change due to the pressure of urbanization can affect the ecology and environmental conditions.

Most of the large and medium-sized cities, for example, Wuhan [60], Cairo, and Kigali [25] have grown in a compact form with an inner core and minimally scattered manner on the outskirts. However, in small cities, such characteristics were not uniformly noted and much more irregular pattern was 
found. Among the six towns, in this study, only Dukem showed as such a trend, while all the rest revealed irregular patterns. Dukem showed growth from the inner core to its periphery in all directions (see Figures 6e and 7f). This town has no shared boundary with Addis Ababa, and could be the reason for its expansion in all directions. Other towns have shared a common boundary with a capital city, and they showed a tendency to expand towards Addis Ababa, following the main road, suggesting a lack of rigorous implementation of the master plan.

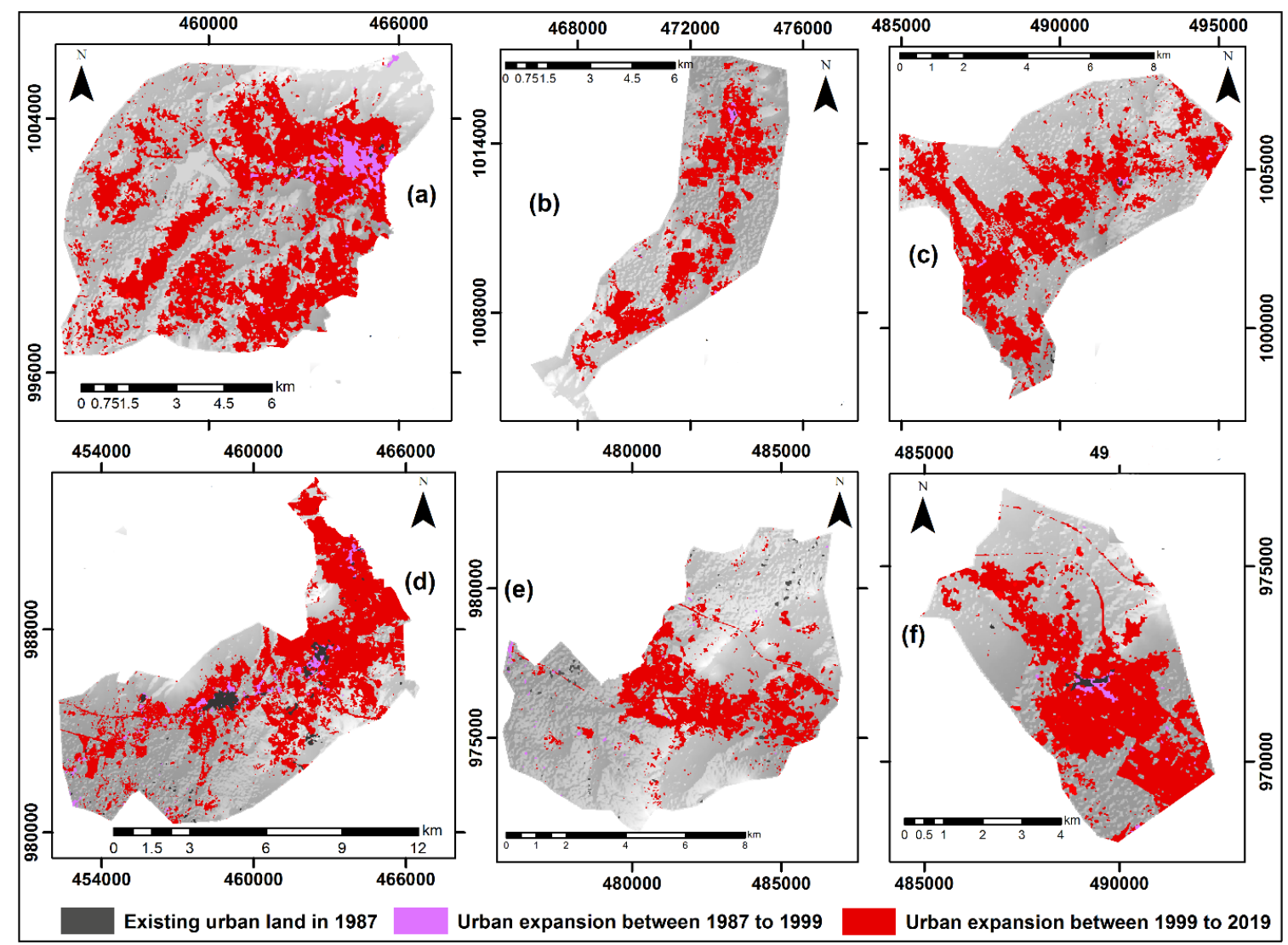

Figure 7. (a-f) Urban expansion map of study site from 1987 to 2019.

The outcome from prior studies $[10,18,37,38,46]$ indicated that rapid urbanization and lack of good monitoring and managing urban development, lead to a shift in the natural ecosystem of the area and the formation of a more fragmented landscape pattern. In this study, ecological service can be deteriorated due to the considerable decrease in the grassland, agriculture, and vegetation ecosystem (Table 8 ). Such a situation (of loss in natural landscape) could be even more aggravated in smaller cities than the other medium-sized cities. For instance, Mekelle and Hawassa, are the third and fourth-largest cities, respectively, of the country. These cites lost 20.8\% [19] and 48.5\% [46] of vegetation cover between the years 1984 to 2014. However, this value was higher in this study. Between 1987 and 2019, coverage of vegetation in Burayu, Sululta, and Lege-Tafo towns were, for example, reduced by $49.5 \%, 51.8 \%$, and $53.64 \%$, respectively (see Table 8 ). This suggests that the small cities in the vicinity of large cities could be strongly impacted in terms of the ecological connectivity than that of the medium cities. 
Table 8. The total percentage of LULC changes from 1987 to 2019 (Percent).

\begin{tabular}{ccccccc}
\hline Classes & Burayu & Sebeta & Lege-Tafo & Sululta & Dekem & Gelan \\
\hline Built-up & 2487.20 & 1978.31 & 20877.78 & 5642.86 & 9284.62 & 9284.62 \\
Agriculture & 11.06 & -32.91 & 64.07 & -13.28 & -21.23 & -21.23 \\
Vegetation & -49.53 & -38.67 & -53.61 & -51.77 & -9.68 & -9.68 \\
Grass & -72.76 & -66.93 & -81.86 & -20.03 & 201.14 & 201.14 \\
\hline
\end{tabular}

\subsection{Urbanization and Its Influences on the Landscape Compositions}

Study results revealed a negative correlation between urban expansion, and green (vegetation and grass), and agricultural area coverage. The rapid increase in the urban area from 1987 to 2019 has resulted in the loss of $21.7 \%$ of cropland across the six towns in the study domain, which can decrease the local agricultural products. A comparable pattern was observed in a similar study made on other regional cities of the country, Bahr Dar [40] and Mekelle [19] though the rates differ. Both studies highlighted population growth as a major influencing factor. Indeed, loss in agricultural farmland initiated by urbanization is widespread across the globe. Similar studies made in Pune Metropolis, India [3] and Benin metropolitan area and Nigeria [61] noted a loss of extensive farmlands due to urbanization. The loss of such large agricultural areas might be due to the urban land-use tends to have a strong revenue per unit of land than agricultural products. However, such kind of trend can affect food securities in countries like Ethiopia with high population growth.

Furthermore, the most significant dynamics related to urban growth is the loss of vegetation cover around the periphery due to the replacement of natural land cover by impervious surfaces. Nevertheless, several studies have suggested that urban expansion is also attributed to a reduction of vegetation cover in the urban center, because of the steady rise in urban density and paving of green spaces $[49,62,63]$. In this investigation, the loss of about $45.3 \%$ of vegetation cover including natural forest, could contribute to the deterioration of the environmental services of a city. An increase in the informal settlement could also be one of the main reasons for the degeneration of green vegetation. The decrease in vegetation covers is mainly because of ineffective land management exercise and less soil protection criteria [38]. This situation highlights the need to consider the balance between urban expansion and green vegetation conservation.

\subsection{Urban Landscape Dynamics and Associated Triggers}

The technologically driven spatial and temporal analysis of this investigation also clearly showed the intensity of urban landscape changes in the study sites. The landscape ecology method implemented in this study contributed to a better understanding of the spatial and temporal dynamics of urban landscape patterns. These landscape metrics permitted a better calculation of the dynamics in spatial composition and configuration inside the urban region and revealed that fragmentation of natural land resources has amplified in all towns over the past 32 years.

According to the landscape metrics analysis, the agro-vegetation patches reduced considerably in composition and became more fragmented in the configuration. The built-up patches grew significantly; however, their structures were more dispersed in all towns, particularly post 1999, which suggests increasing urban sprawl. A similar trend has been observed over many small cities around the world such as Josi, Nigeria [32], Kurukshetra, India [64], and Idaho, USA [22], which is indicative of a dispersed urban growth. As compared with the latest study periods, a relatively stable landscape fragmentation was recorded in the year between 1987 and 1999. Eventually, landscape fragmentation significantly increased during the second study period of urbanization. Thus, a significant fragmentation and increased complexity of the natural land covers/urban landscape distribution is evident due to the influence of isolated and unstructured urban growth. This is indicative of the development of small urban patches around the outlying of the city and along the major roads. Such ad-hoc development also highlights unregulated urban expansion patterns [15,19,21,42,57,65]. Enaruvbe and Atafo (2018) 
suggested the loss of farming land in recent years might also be a sign of the periurban land becoming urban due to the higher land price in the city center and more accessible urban fringes. Thus, unless appropriately managed, fragmented urban growth is inefficient economically well as ecologically unfriendly $[2,18,22]$.

The rapid growth of urban areas and the fragmented urban landscape of the six towns since 1999 is also indicative of the policy shift towards urbanization and industrialization that has significantly contributed to the rapid transformation of the Ethiopian economy [43]. The increase in the urban area is also associated with population growth. For instance, the population of Sebeta increased by about $612 \%$, from 24,924 in 1999 to 177,370 in 2019 , and the built-up area increased by about $1307 \%$ during the same study period (see Table 6). This suggested that the urban expansion rate follows the population growth and could be much larger than the population growth rate. Similar trends have been reported for other Ethiopian cities as Addis Ababa, Mekelle, and Bahir Dar [15,19,40,42]. Hawassa city has shown that population growth exceeds the urban expansion rate [15]. This is likely associated with informal settlements, as evidenced by increasingly fragmented and complicated patterns of the urban landscape at the fringes of the city (Figure 6). Furthermore, the towns are closer to the capital city, Addis Ababa, and have the advantage of access to trained labor, infrastructure, and financial services. As a result, businesses tend to establish in these cities. As feedback, this led to the immigration of employment seekers from other parts of the country, resulting in further rapid and scattered urban growth and high fragmented natural landscape patterns.

The urbanization process in the Oromia Special Zone surrounding Finfinnee towns is clearly influenced by their distance from Addis Ababa. The towns with the shortest distance from Addis Ababa have a relatively high stage of urban agglomeration. Except for Dukem, all towns expanded surrounding Addis Ababa. Interestingly, Dukem also has the smallest size relative to the other towns. In addition, the expansion of these towns was influenced by 'pulling' forces such as governmental institutions and policies and 'pushing' forces such as industrial investment, and access infrastructures (e.g., along with Gelan and Dukem towns), and market for the urban land, in which the price of land is lower at the outskirt. This resulted in the intensified trend of dispersed urban land expansion in these towns. The socioeconomic, cultural, political, and biophysical reflections are the main drivers of land-use trends in several countries and could not be explicitly analyzed [5,42].

\subsection{Patterns of Urban Spatial Growth}

The built-up density (BD) analysis with distance buffer zones suggests that the built-up areas continue to be dense in the core town, related to infill and extension growth. Nevertheless, the class of built-up areas became disconnected and dispersed on the periphery, attributable to outward and leapfrog development. The dispersion of the urban landscape may be a result of new urban land development around the fringes of the town. However, in most African cities, particularly in Ethiopia, dispersed urban growth is a result of unplanned and uncontrolled manners of newly developed urban areas, which is connected with the informal settlements [15,42].

\section{Conclusion}

Controlling the fragmentation of landscape in ecologically sensitive regions is essential to conserve agro-vegetation ecosystems. A detailed understanding of such change provides to design holistic strategies intended at controlling the landscape fragmentation and enhancing agro-vegetation connectivity in urban outskirts areas. Understanding urban growth processes and identifying these patterns at a different distance from the city center is vital to manage and plan urbanization processes. Thus, the study comprehensively characterized and compared spatiotemporal landscape dynamics structures and urban expansion patterns in six towns of the Oromia Special Zone surrounding Finfinnee, Ethiopia, using spatially explicit Landsat imagery with combined multiple approaches over the 1987-2019 period. 
The results revealed that: (1) all towns under the study experienced accelerated growth in the built-up area, scattered urban spatial growth along the outskirts, and irregular patterns of built-up density. Such an increase may indicate a lack of rigorous implementation of the urban master plan. (2) A significant loss of natural land covers, fragmented, and complicated agro-vegetation patches. In that, it could be inferred that the intensity of human activities influences land-use dynamics, ecological change, and landscape fragmentation. (3) The role of urban planning and management, population, policy, and distance to the capital city emerge as driving forces for the expansion of towns. (4) It also found that the highest urban development, the most dispersed urban growth and the landscape fragmentation period were observed during the year 1999-2019. Concurrently, the rapid increase in the urbanized areas has resulted in a loss of $38.45 \%$ of natural land cover. This is indicative that the recently created zone, the Oromia Special Zone surrounding Finfinnee did not control or contain the rapid urban sprawl. It can be postulated that the corresponding reduction in food production might affect and shift to nearby areas, and there might be a probability of flood risk and environmental deterioration due to the significant loss of natural land cover. This situation sounds an alarm warning to consider the balance between urban expansion and green vegetation conservation for improved urban ecosystem services and enhanced liveability. Thus, urban changes need to consider and evolve with green areas, agricultural modernization, and new rural development following the policies based on scientific planning and steady progress. Indeed, sustainable urban growth not only can successfully improve land-use efficiency and promote regional economic, but also plays a vital role in social harmony.

More broadly, the study concluded that even though small cities would have limited footprint and demographic size and have less contribution to the national economic agglomeration, they can still be important for the region's ecological and environmental services. To curtail the continuous degradation of land that appears to be underway, the study suggests that policies controlling influences of human disturbance and ecological barriers should develop robust conservation of landscape and in particular, seek to reduce-edge effects by controlling urban sprawl in the agro-vegetation system.

The proposed methods in this study can help in identifying the priority areas to be selected for conservation, ecological improvements, urban densifications, and agro-forest system restoration. The findings from the study can help planners and decision-makers in developing sustainable strategies for landscape planning and management. The outcomes from such research could also help to postulate theories and generalize the state of urbanization process and dynamics of the landscape patterns with particular focus on small cities and towns.

Author Contributions: Conceptualization, B.K.T. and N.C.; methodology, B.K.T.; software, B.K.T.; validation, B.K.T., N.C., and X.Z.; formal analysis, B.K.T.; investigation, B.K.T.; resources, N.C.; data curation, B.K.T.; writing—original draft preparation, B.K.T.; writing—review and editing, B.K.T., N.C., X.Z., and D.N.; visualization, B.K.T., N.C., and X.Z.; supervision, N.C.; project administration, N.C.; funding acquisition, N.C. and X.Z. All authors have read and agreed to the published version of the manuscript.

Funding: This research was supported in part by the National Key R\&D Program (no.2018YFB2100500), National Natural Science Foundation of China program (no.41890822, 41801339), Creative Research Groups of Natural Science Foundation of Hubei Province of China (no.2016CFA003), and U.S. NSF OAC-1835739.

Acknowledgments: We would like to express our respects and appreciation to the reviewers and editors for their professional comments and suggestions.

Conflicts of Interest: The authors declare no conflicts of interest.

\section{References}

1. Bhatta, B.; Saraswati, S.; Bandyopadhyay, D. Urban Sprawl Measurement from Remote Sensing Data. Appl. Geogr. 2010, 30, 731-740. [CrossRef]

2. Ewing, R.; Hamidi, S. Compactness versus Sprawl: A Review of Recent Evidence from the United States. J. Plan. Lit. 2015, 30, 413-432. [CrossRef]

3. Kantakumar, L.N.; Kumar, S.; Schneider, K. Spatiotemporal Urban Expansion in Pune Metropolis, India Using Remote Sensing. Habitat Int. 2016, 51, 11-22. [CrossRef] 
4. Kowalczyka, C.; Kil, J.; Kurowska, K. Dynamics of Development of the Largest Cities—Evidence from Poland. Cities 2019, 89, 26-34. [CrossRef]

5. Colsaet, A.; Laurans, Y.; Levrel, H. Land Use Policy What Drives Land Take and Urban Land Expansion? A Systematic Review. Land Use Policy 2018, 79, 339-349. [CrossRef]

6. Mcdonald, R.I.; Weber, K.; Padowski, J.; Flo, M.; Schneider, C.; Green, P.A.; Gleeson, T.; Eckman, S.; Montgomery, M.; Lehner, B.; et al. Water on an Urban Planet: Urbanization and the Reach of Urban Water Infrastructure. Glob. Environ. Chang. 2014, 27, 96-105. [CrossRef]

7. Ananda, J.; Hampf, B. Measuring Environmentally Sensitive Productivity Growth: An Application to the Urban Water Sector. Ecol. Econ. 2015, 116, 211-219. [CrossRef]

8. Wu, W.; Zhao, S.; Zhu, C.; Jiang, J. A Comparative Study of Urban Expansion in Beijing, Tianjin and Shijiazhuang over the Past Three Decades. Landsc. Urban Plan. 2015, 134, 93-106. [CrossRef]

9. Peng, J.; Xie, P.; Liu, Y.; Ma, J. Remote Sensing of Environment Urban Thermal Environment Dynamics and Associated Landscape Pattern Factors: A Case Study in the Beijing Metropolitan Region. Remote Sens. Environ. 2016, 173, 145-155. [CrossRef]

10. Cao, H.; Liu, J.; Chen, J.; Gao, J.; Zhang, W.; Wang, G.; Zhang, W. Spatiotemporal Patterns of Urban Land Use Change in Typical Cities in the Greater Mekong. Remote Sens. 2019, 11, 801. [CrossRef]

11. Magidi, J.; Ahmed, F. The Egyptian Journal of Remote Sensing and Space Sciences Assessing Urban Sprawl Using Remote Sensing and Landscape Metrics: A Case Study of City of Tshwane, South Africa (1984-2015). Egypt. J. Remote Sens. Sp. Sci. 2018. [CrossRef]

12. Liu, D.; Chen, N.; Zhang, X.; Wang, C.; Du, W. Annual Large-Scale Urban Land Mapping Based on Landsat Time Series in Google Earth Engine and OpenStreetMap Data: A Case Study in the Middle Yangtze River Basin. ISPRS J. Photogramm. Remote Sens. 2020, 159, 337-351. [CrossRef]

13. Akbar, T.A.; Hassan, Q.K.; Ishaq, S.; Batool, M.; Butt, H.J. Investigative Spatial Distribution and Modelling of Existing and Future Urban Land Changes and Its Impact on Urbanization and Economy. Remote Sens. 2019, 11, 105. [CrossRef]

14. Kuang, W.; Chi, W.; Lu, D.; Dou, Y. A Comparative Analysis of Megacity Expansions in China and the U.S.: Patterns Rates and Driving Forces. Landsc. Urban Plan. 2014, 132, 121-135. [CrossRef]

15. Terfa, B.K.; Chen, N.; Liu, D.; Zhang, X.; Niyogi, D. Urban Expansion in Ethiopia from 1987 to 2017 : Characteristics, Spatial Patterns, and Driving Forces. Sustainability 2019, 11, 2973. [CrossRef]

16. Fang, C.; Zhao, S. A Comparative Study of Spatiotemporal Patterns of Urban Expansion in Six Major Cities of the Yangtze River Delta from 1980 to 2015. Ecosyst. Heal. Sustain. 2018, 4, 95-114. [CrossRef]

17. Shukla, A.; Jain, K. Critical Analysis of Spatial-Temporal Morphological Characteristic of Urban Landscape. Arab. J. Geosci. 2019, 12. [CrossRef]

18. Dutta, I.; Das, A. Application of Geo-Spatial Indices for Detection of Growth Dynamics and Forms of Expansion in English Bazar Urban Agglomeration, West Bengal. J. Urban Manag. 2019, 8, 288-302. [CrossRef]

19. Fenta, A.A.; Yasuda, H.; Haregeweyn, N.; Belay, A.S.; Hadush, Z.; Gebremedhin, M.A.; Mekonnen, G. The Dynamics of Urban Expansion and Land Use/Land Cover Changes Using Remote Sensing and Spatial Metrics: The Case of Mekelle City of Northern Ethiopia. Int. J. Remote Sens. 2017, 38, 4107-4129. [CrossRef]

20. Fahmi, F.Z.; Hudalah, D.; Rahayu, P.; Woltjer, J. Extended Urbanization in Small and Medium-Sized Cities: The Case of Cirebon, Indonesia. Habitat Int. 2014, 42, 1-10. [CrossRef]

21. Hernández-moreno, Á.; Reyes-paecke, S. The effects of Urban Expansion on Green Infrastructure along an Extended Latitudinal Gradient $\left(23^{\circ} \mathrm{S}-45^{\circ} \mathrm{S}\right)$ in Chile over the Last Thirty Years. Land Use Policy 2018, 79 , 725-733. [CrossRef]

22. Felt, C.; Fragkias, M.; Larson, D.; Liao, H.; Lohse, K.A.; Lybecker, D. A Comparative Study of Urban Fragmentation Patterns in Small and Mid-Sized Cities of Idaho. Urban Ecosyst. 2018. [CrossRef]

23. United Nations Department of Economic and Social Affairs Population Division. The World's Cities in 2018-Data Booklet (ST/ESA/ SER.A/417). 2018. Available online: https://www.un.org/en/development/ desa/population/publications/pdf/urbanization/the_worlds_cities_in_2018_data_booklet.pdf (accessed on 13 January 2019).

24. Vanderhaegen, S.; Canters, F. Mapping Urban Form and Function at City Block Level Using Spatial Metrics. Landsc. Urban Plan. 2017, 167, 399-409. [CrossRef] 
25. Xu, G.; Dong, T.; Brandful, P.; Jiao, L.; Sumari, N.S.; Chai, B.; Liu, Y. Urban Expansion and Form Changes across African Cities with a Global Outlook: Spatiotemporal Analysis of Urban Land Densities. J. Clean. Prod. 2019, 224, 802-810. [CrossRef]

26. Liu, D.; Chen, N. Satellite Monitoring of Urban Land Change in the Middle Yangtze River Basin Urban Agglomeration, China between 2000 and 2016. Remote Sens. 2017, 9, 1086. [CrossRef]

27. Dong, T.; Jiao, L.; Xu, G.; Yang, L.; Liu, J. Towards Sustainability? Analyzing Changing Urban Form Patterns in the United States, Europe, and China. Sci. Total Environ. 2019, 671. [CrossRef]

28. Sapena, M.; Ruiz, L.Á. Analysis of Land Use/Land Cover Spatio-Temporal Metrics and Population Dynamics for Urban Growth Characterization. Comput. Environ. Urban Syst. 2019. [CrossRef]

29. Viana, C.M.; Oliveira, S.; Oliveira, S.C.; Rocha, J. Land Use/Land Cover Change Detection and Urban Spraw1 Analysis. Spat. Model. GIS R Earth Environ. Sci. 2019, 621-651. [CrossRef]

30. Tian, G.; Jiang, J.; Yang, Z.; Zhang, Y. The Urban Growth, Size Distribution and Spatio-Temporal Dynamic Pattern of the Yangtze River Delta Megalopolitan Region, China. Ecol. Model. 2011, 222, 865-878. [CrossRef]

31. Nor, A.N.M.; Corstanje, R.; Harris, J.A.; Brewer, T. Impact of Rapid Urban Expansion on Green Space Structure. Ecol. Indic. J. 2017, 81, 274-284. [CrossRef]

32. Akintunde, J.A.; Adzandeh, E.A.; Fabiyi, O.O. Spatio-Temporal Pattern of Urban Growth in Jos Metropolis, Nigeria. Remote Sens. Appl. Soc. Environ. 2016, 4, 44-54. [CrossRef]

33. Li, X.; Zhou, W. Optimizing Urban Greenspace Spatial Pattern to Mitigate Urban Heat Island Effects: Extending Understanding from Local to the City Scale. Urban For. Urban Green. 2019, 41, 255-263. [CrossRef]

34. Masoudi, M.; Tan, P.Y. Multi-Year Comparison of the Effects of Spatial Pattern of Urban Green Spaces on Urban Land Surface Temperature. Landsc. Urban Plan. 2019, 184, 44-58. [CrossRef]

35. Yue, W.; Liu, X.; Zhou, Y.; Liu, Y. Impacts of Urban Configuration on Urban Heat Island: An Empirical Study in China Mega-Cities. Sci. Total Environ. 2019, 671, 1036-1046. [CrossRef]

36. Grigora, G.; Uri, B. Land Use/Land Cover Changes Dynamics and Their Effects on Surface Urban Heat Island in Bucharest, Romania. Int. J. Appl. Earth Obs. Geoinf. 2019, 80, 115-126. [CrossRef]

37. Dadashpoor, H.; Azizi, P.; Moghadasi, M. Land Use Change, Urbanization, and Change in Landscape Pattern in a Metropolitan Area. Sci. Total Environ. 2019, 655, 707-719. [CrossRef]

38. Pili, S.; Serra, P.; Salvati, L. Landscape and the City: Agro-Forest Systems, Land Fragmentation and the Ecological Network in Rome, Italy. Urban For. Urban Green. 2019, 41, 230-237. [CrossRef]

39. Sumari, N.S.; Xu, G.; Ujoh, F.; Korah, P.I.; Ebohon, O.J.; Lyimo, N.N. A Geospatial Approach to Sustainable Urban Planning: Lessons for Morogoro Municipal. Sustainability 2019, 11, 6508. [CrossRef]

40. Haregeweyna, N.; Fikadub, G.; Atsushi, T.; Tsuboa, M.; Meshesha, D.T. The Dynamics of Urban Expansion and Its Impacts on Land Use/Land Cover Change and Small-Scale Farmers Living near the Urban Fringe: A Case Study of Bahir Dar, Ethiopia. Landsc. Urban Plan. 2012, 106, 149-157. [CrossRef]

41. Ministry of Urban Development Housing and Construction (MUDHCo). National Report on Housing on Housing and Sustainable Urban Development. 2014. Available online: https://unhabitat.org/wp-content/ uploads/2014/07/Ethiopia-National-Report.pdf (accessed on 13 January 2019).

42. Zewdie, M.; Worku, H.; Bantider, A. Temporal Dynamics of the Driving Factors of Urban Landscape Change of Addis Ababa during the Past Three Decades. Environ. Manag. 2018, 61, 132-146. [CrossRef]

43. United Nations Human Settlements Programme (UN-Habitat). The State of Addis Ababa 2017: The Addis Ababa We Want; UN-Habitat: Nirobi, Kenya, 2017; Available online: https:/unhabitat.org/books/the-state-of-addisababa-2017-the-addis-ababa-we-want (accessed on 16 January 2018).

44. Shiferaw, A. Productive Capacity and Economic Growth in Ethiopia. United Nations Department of Economic and Social Affairs; Department of Economic \& Social Affairs: New York, NY, USA, 2017; Available online: https://www.un.org/development/desa/dpad/wp-content/uploads/sites/45/publication/CDP_BP34_ April_2017.pdf (accessed on 17 February 2019).

45. Kassahun, S.; Tiwari, A. Urban Development in Ethiopia: Challenges and Policy Responses Urban Development in Ethiopia. IUP J. Gov. Public Policy 2012, 7, 59-65. Available online: https://www. academia.edu/22427119/Urban_Development_in_Ethiopia_Challenges_and_Policy_Responses (accessed on 11 March 2019).

46. Nigatu, W.; Dick, Ø.B.; Tveite, H. Landscape Mapping to Quantify Degree-of-Freedom, Degree-of-Sprawl, and Degree-of-Goodness of Urban Growth in Hawassa, Ethiopia. Environ. Nat. Resour. Res. 2014, 4, $223-237$. [CrossRef] 
47. Mohamed, A.; Worku, H. Quantification of the Land Use/Land Cover Dynamics and the Degree of Urban Growth Goodness for Sustainable Urban Land Use Planning in Addis Ababa and the Surrounding Oromia Special Zone. J. Urban Manag. 2018. [CrossRef]

48. Tadesse, E.; Imana, G. Prospects and Challenges of Urbanization on the Livelihood of Farming Community Surrounding Finfinne. Am. Res. J. Humanit. Soc. Sci. I 2017, 3, 1-15.

49. Fonseka, H.P.U.; Zhang, H.; Sun, Y.; Su, H.; Lin, H.; Lin, Y. Urbanization and Its Impacts on Land Surface Temperature in Colombo Metropolitan Area, Sri Lanka, from 1988 to 2016. Remote Sens. 2019, 11, 957. [CrossRef]

50. Zhou, D.; Zhao, S.; Zhu, C. The Grain for Green Project Induced Land Cover Change in the Loess Plateau: A Case Study with Ansai County, Shanxi Province, China. Ecol. Indic. 2012, 23, 88-94. [CrossRef]

51. Zhao, S.; Zhou, D.; Zhu, C.; Qu, W.; Zhao, J.; Sun, Y. Rates and Patterns of Urban Expansion in China's 32 Major Cities over the Past Three Decades. Landsc. Ecol. 2015, 30, 1541-1559. [CrossRef]

52. McGarigal, K.; Cushman, S.A.; Neel, M.C.; Ene, E. FRAGSTATS: Spatial Pattern Analysis Program for Categorical Maps. Computer Software Program. 2015. Available online: https://www.umass.edu/landeco/ research/fragstats/documents/fragstats.help.4.2.pdf (accessed on 21 May 2018).

53. Wu, J.; Jenerette, G.D.; Buyantuyev, A.; Redman, C.L. Quantifying Spatiotemporal Patterns of Urbanization: The Case of the Two Fastest Growing Metropolitan Regions in the United States. Ecol. Complex. 2011, 8, 1-8. [CrossRef]

54. Zhou, W.; Wang, J.; Cadenasso, M.L. Effects of the Spatial Configuration of Trees on Urban Heat Mitigation: A Comparative Study. Remote Sens. Environ. 2017, 195, 1-12. [CrossRef]

55. Rempel, R.S.; Kaukinen, D.; Carr, A.P. Patch Analyst and Patch Grid; Centre for Northern Forest Ecosystem Research; Ontario Ministry of Natural Resources: Thunder Bay, ON, Canada, 2012. Available online: http://www.cnfer.on.ca/SEP/patchanalyst/ (accessed on 24 October 2018).

56. Zhang, S.; York, A.M.; Boone, C.G.; Shrestha, M. Methodological Advances in the Spatial Analysis of Land Fragmentation. Prof. Geogr. 2013, 65, 512-526. [CrossRef]

57. Díaz-palacios-sisternes, S.; Ayuga, F.; García, A.I. A Method for Detecting and Describing Land Use Transformations: An Examination of Madrid's Southern Urban-Rural Gradient between 1990 and 2006. Cities 2014. [CrossRef]

58. Sun, Y.; Zhao, S. Spatiotemporal Dynamics of Urban Expansion in 13 Cities across the Jing-Jin-Ji Urban Agglomeration from 1978 to 2015. Ecol. Indic. 2018, 87, 302-313. [CrossRef]

59. Sahana, M.; Hong, H.; Sajjad, H. Analyzing Urban Spatial Patterns and Trend of Urban Growth Using Urban Sprawl Matrix: A Study on Kolkata Urban Agglomeration, India. Sci. Total Environ. 2018, 628-629, 1557-1566. [CrossRef] [PubMed]

60. Jiao, L. Urban Land Density Function: A New Method to Characterize Urban Expansion. Landsc. Urban Plan. 2015, 139, 26-39. [CrossRef]

61. Enaruvbe, G.O.; Atafo, O.P. Land Cover Transition and Fragmentation of River Ogba Catchment in Benin City, Nigeria. Sustain. Cities Soc. 2018, 45, 70-78. [CrossRef]

62. Escobedo, F.J.; Palmas-perez, S.; Dobbs, C.; Gezan, S.; Hernandez, J. Spatio-Temporal Changes in Structure for a Mediterranean Urban Forest: Santiago, Chile 2002 to 2014. Forests 2016, 7, 121. [CrossRef]

63. Dobbs, C.; Nitschke, C.; Kendal, D. Assessing the Drivers Shaping Global Patterns of Urban Vegetation Landscape Structure. Sci. Total Environ. 2017, 592, 171-177. [CrossRef]

64. Anees, M.M.; Shafa, S.; Joshi, P.K. Characterizing Urban Area Dynamics in Historic City of Kurukshetra, India, Using Remote Sensing and Spatial Metric Tools. Geocarto Int. 2018, 34, 1584-1607. [CrossRef]

65. Girma, Y.; Terefe, H.; Pauleit, S.; Kindu, M. Urban Green Infrastructure Planning in Ethiopia: The Case of Emerging Towns of Oromia Special Zone Surrounding Finfinne. J. Urban Manag. 2019, 8, 75-88. [CrossRef]

(C) 2020 by the authors. Licensee MDPI, Basel, Switzerland. This article is an open access article distributed under the terms and conditions of the Creative Commons Attribution (CC BY) license (http://creativecommons.org/licenses/by/4.0/). 